\title{
Multidimensional scaling approach to evaluate the level of community forestry sustainability in Babak Watershed, Lombok Island, West Nusa Tenggara
}

\author{
Ryke Nandini *,1, Ambar Kusumandari², Totok Gunawan ${ }^{3}$, Ronggo Sadono ${ }^{2}$ \\ ${ }^{1}$ Doctoral Program of Forest Science, Faculty of Forestry, Universitas Gadjah Mada \\ Jl. Agro No. 1 Bulaksumur, Yogyakarta 55281 \\ ${ }^{2}$ Faculty of Forestry Universitas Gadjah Mada, Jl. Agro No. 1 Bulaksumur, Yogyakarta 55281 \\ ${ }^{3}$ Faculty of Geography Universitas Gadjah Mada, Jl. Kaliurang, Bulaksumur, Yogyakarta 55281 \\ * Corresponding author (e-mail: rykenand@yahoo.com)
}

Received: 13 February 2017 / Accepted: 13 March 2017/ Published: 01 July 2017

\begin{abstract}
Community forestry in Babak watershed is one of the efforts to reduce critical land area. The aim of this research was to evaluate the level of community forestry sustainability in both of community forest $(\mathrm{HKm})$ and private forest in Babak watershed. Multidimensional scaling (MDS) was used to analyse the level of community forest sustainability based on the five dimensions of ecology, economy, social, institutional, and technology as well as 29 attributes. Leverage analysis was used to know the sensitive attributes of sustainability, while Monte Carlo analysis and goodness of fit was used to find the accuracy of MDS analysis. The result shows that $\mathrm{HKm}$ was in moderate sustainability level (sustainability index $54.08 \%$ ) and private forest was in less sustainability level (sustainability index 48.53\%). Furthermore, the ecology and technology in HKm were classified as less sustainable, while the institution and technology in private forest were considered less sustainable. There were 11 sensitive attributes of $\mathrm{HKm}$ and 19 sensitive attributes of private forest. The priorities of attribute improvement in HKm include land recovering (the dimension of ecology) and cooperative development (the dimension of technology). In private forest, the priorities of attribute improvement include leadership capacity building (the institutional dimension) and also the use of silviculture intensive and soil conservation (the dimension of technology).
\end{abstract}

Keywords: Babak watershed, leverage analysis, Monte Carlo analysis, multidimensional scaling, sustainability index.

Abstrak. Kegiatan kehutanan masyarakat di DAS Babak merupakan salah satu upaya untuk mengurangi lahan kritis. Tujuan penelitian ini adalah mengetahui tingkat keberlanjutan kehutanan masyarakat baik HKm maupun hutan rakyat di DAS Babak. Metode yang digunakan pada penelitian ini adalah multidimensional scaling (MDS) yang terdiri dari lima dimensi (ekologi, ekonomi, sosial, kelembagaan dan teknologi) dan 29 atribut sebagai dasar penilaian indeks keberlanjutan. Analisis leverage digunakan untuk menentukan atribut yang sensitif terhadap indeks keberlanjutan, sedangkan analisis Monte Carlo dan analisis ketepatan digunakan untuk mengetahui keakuratan analisis MDS. Hasil analisis diketahui bahwa HKm berada pada tingkat cukup berkelanjutan (nilai indeks 54,08\%) dan hutan rakyat pada tingkat kurang berkelanjutan (nilai indeks 48,53\%). Dimensi ekologi dan teknologi merupakan dimensi kurang berkelanjutan pada HKm, sedangkan dimensi kelembagaan dan teknologi merupakan dimensi yang kurang berkelanjutan pada hutan rakyat. Pada HKm terdapat 11 atribut sensitif sedangkan pada hutan rakyat terdapat 19 atribut sensitif terhadap tingkat keberlanjutan. Perbaikan atribut pada HKm dapat dilakukan dengan perbaikan penutupan lahan (dimensi ekologi) serta pembentukan koperasi (dimensi teknologi). Perbaikan atribut pada hutan rakyat dapat dilakukan dengan peningkatan kepemimpinan (dimensi kelembagaan) serta penggunaan silvikultur intensif dan konservasi tanah dan air (dimensi teknologi).

Kata Kunci: analisis leverage, analisis Monte Carlo, DAS Babak, indeks keberlanjutan, MDS. 


\section{Introduction}

Marginal land is one of complicated environmental issues that has not been overcome yet. According to Kementerian Kehutanan (2014), deforestation rates in 20112012 reached 613,480.7 hectares, whereas the productive land and forest rehabilitation was only 15,000 hectares per year. Babak watershed is a restored watershed (Murtilaksono, 2014). Based on BP DAS Dodokan Moyo Sari (2008), the increase of critical land in period 20082014 was very high, which was almost $42.27 \%$. The critical land has caused the environment degradation, thus, the priority to overcome this issue is required. There are some impacts of critical land to the environmental quality, such as the economic value and water quality (Fiquepron et al., 2013), discharge and sedimentation (Yan et al., 2013), erosion, biodiversity and air quality (Li et al., 2013), and also physicochemical and soil biology (Hazarika et al., 2014).

The critical land is strongly associated with the land utilisation. The land utilisation requires an accurate regulation (Nunes et al., 2011; Li et al., 2013) to prevent and rehabilitate the critical land. Forest is considered as the solution to overcome the prevalence of critical land. As the forest functioning, forest and vegetation have an important role in response to flooding and drought, precipitation, and in some cases can improve the discharge (Asdak, 2010). Forest also has a major role in climate change adaptation, mitigation activity including carbon sink, as well as the environment goods and service provider, biodiversity, recharge area, and food reserves providers to face the drought period which is susceptible to climate change (Nkem, 2006).

The efforts of critical land recovery should involve the community participation, including by promoting community forestry both within and outside of the forest area based on the scheme of land and forest rehabilitation. The activity of community forestry within the forest area is known as community forest $(\mathrm{HKm})$, while those outside the forest area is known as a private forest. The policies in pertaining with community forestry have two important roles, namely to increase the economic aspect (Khanal 2011; Irawanti et al., 2012; Aji et al., 2015) and to restore the environment quality (Rahayu et al., 2010; Irawan, 2011; Ritonga \& Rochana, 2013; Nurwanti, 2014). Therefore, the performance of community forestry to address the critical land problem can be assessed from the models of community forestry, which determine the sustainability benefit for the ecology and social economy of the community. The sustainable community forestry should be formulated based on the criteria and indicators that can determine the goal of community forestry.

Pokharel et al. (2015) stated that the sustainability can be evaluated based on four criteria of forest resources, social economic benefit, forest management practices, and institutional and governance framework, which are specified into 26 indicators. Awang et al. (2008) suggested that some criteria that can be used to evaluate the sustainability are ecology, institution of forest management, community income, and also social condition. Meanwhile, Pikun (1998) formulated the sustainability of community forestry or social forestry can be identified from the factors of ecology, social (regarding community participation), management (in terms of land management and farmer group organisation), and also economy (productivity and product marketing). From those formulations, the ecology, economy, social, institution and land management are used as the basic of community forest evaluation as included in BP DAS Dodokan Moyo Sari (2008) and Nandini (2013).

The identification of the sustainability level of community forestry is required to arrange the improvement in order to attain the goals. Furthermore, the sustainability evaluation can be done either by using manual scoring or software based on multidimensional scaling (MDS). Nandini (2013) examined the community forest in $\mathrm{HKm}$ Darussadiqien located in the upstream of Babak watershed by using manual scoring, whileSukwika etal. (2016) examined the sustainability of private forest in Bogor by using MDS. MDS was employed by Pitcher and Preikshot (2001) as the tool to 
evaluate the sustainability of fisheries, which is known as Rapfish and further developed for various fields such as RapPforest (Sukwika et al., 2016), RapLandUse (Widiatmaka et al., 2015), RALED (Budiharsono, 2014), RapSisprodi (Nazam et al., 2011), and also
RapDAS (Suwarno et al., 2011). In this regard, the aim of this research was to evaluate the sustainability level of community forestry both of community forest $(\mathrm{HKm})$ and private forest in Babak watershed by using RapCF, which was developed from MDS.

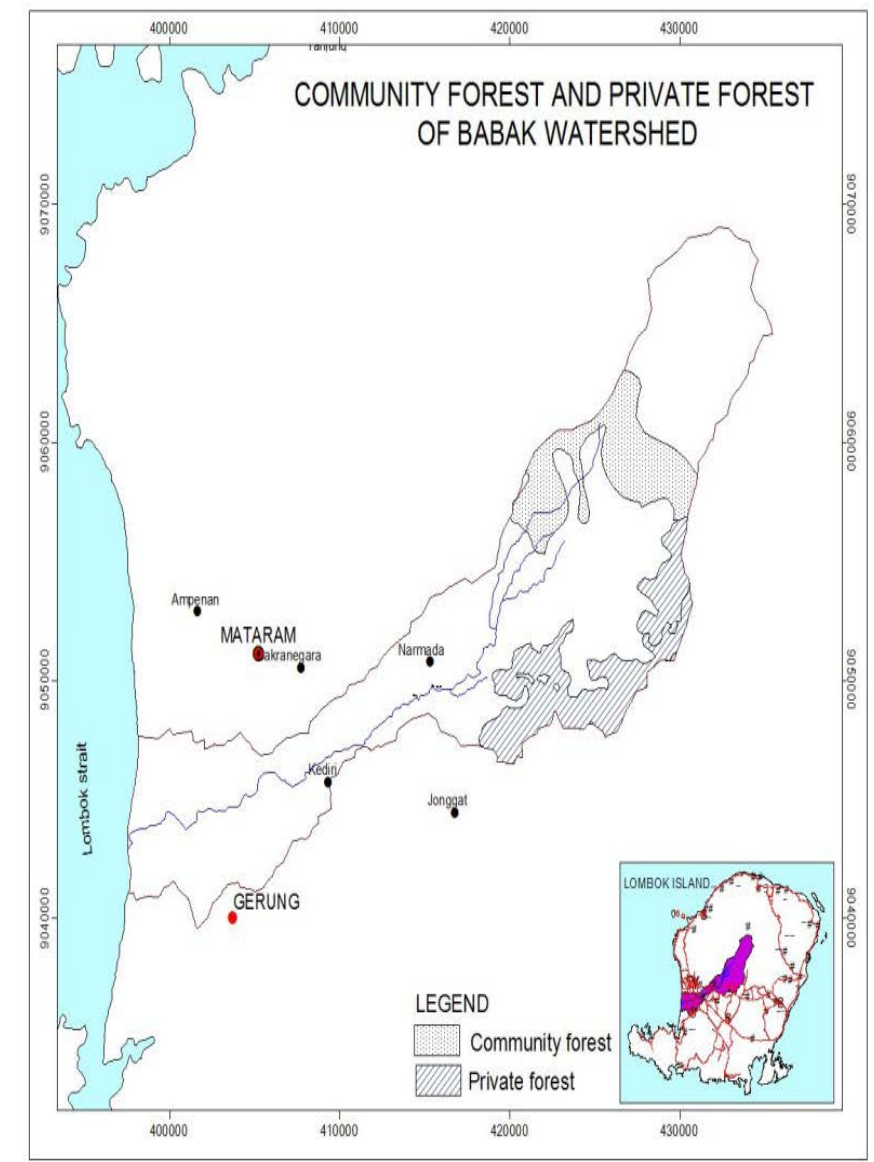

Figure 1. Community forest and private forest in Babak watershed

\section{Research Method}

\section{a. Study Area}

This research was conducted in the community forest and private forest in Babak watershed, Lombok Island, West Nusa Tenggara. It was conducted from April to July 2015. Babak watershed is located on $8^{\circ} 42^{\prime}-8^{\circ} 67^{\prime}$ in the South and $116^{\circ} 07^{\prime}-116^{\circ} 39^{\prime}$ in the East with a total area of $29,948.39$ hectares. Babak watershed is situated in the centre of Lombok Island with the area coverage of the North and Middle Lombok districts in the upstream and midstream and also Mataram municipally and West Lombok district in the downstream. Most of Babak watershed is the part of Rinjani Mount. The dominated geology is andesite in the upstream, basaltic in the midstream, and alluvium in the downstream of Babak watershed. It is also dominated by the slope of 0-8\% (34.53\%), the soil type of Brown Regosols and Lithosols $(27.55 \%)$, and the land use of shrub (25.06\%). The average annual rainfall is $1854.4 \mathrm{~mm}$ with four dry months and seven wet months in a year and classified as " $B$ " type of climate (almost wet).

Babak watershed is one of the critical watersheds in Lombok Island, which is listed as the national strategic of watershed (the Presidential Decree No. 12 of 2012). Some potential features of Babak watershed include the natural tourism, water resources, and community forestry in which the last feature 
became a pilot project in Lombok Island. In 2008-2014, the critical land in Babak watershed increased significantly. In 2014, Murtilaksono reported that Babak watershed was one of restored watershed that must be revitalised immediately. The community forestry is one of the rehabilitation efforts initiated by the government to solve the critical land issue by involving the community participation. The HKm is located in the upstream of Babak watershed with a total area of $1,809.5$ hectares, while the private forest is located in the midstream of Babak watershed with a total area of $1,702.2$ hectares (Figure 1). Since HKm is located in the forest area, the local communities who manage the forest must have the license of community forest management (IUPHKm) issued by the government. Meanwhile, the private forest is located in the private/ individual land. Hence they are free to manage their lands.

\section{b. Data Collection}

The data was collected through interviews with the farmers in the community forest and private forest as the respondents. The parameters included the aspects of demography (age and gender), ecology (land productivity, soil conservation, land cover, vegetation density, and land cultivation area), economy (community forestry products, product market, contribution of forestry community income, contribution of non-forestry community income, poverty level, family member of dependants, adaptation on agricultural commodities demand), social (education level, perception on soil conservation, perception on community forestry activity, participation in community forestry), institution(farmers groups activity, farmers accompaniment, knowledge of institutional rules, decisionmaking process, and leadership), and also the use of technology (land preparation, planting, plant maintenance, harvesting, postharvest processing, and soil conservation). The respondents of each group of community forestry were determined randomly based on the Slovin's formula (Sevillla et al., 2007) with a significance level of $10 \%$. The total numbers of respondents were 147 farmers. Respondents from $\mathrm{HKm}$ were the members of four farmer groups in Setiling, Aik Berik, Karang Sidemen and Lantan. Furthermore, the respondents of private forest were the members of three farmer groups in Pemepek, Setiling, and Sepakek. In $\mathrm{HKm}$, the respondents aged 24 to 75 years old, the dominant education was elementary school, the average number of dependants was 3 (three) people, and the average cultivated land was $0.64 \mathrm{ha} /$ farmer. Meanwhile in private forest, it was dominated by the respondents aged 27 to 70 years old, education background was senior secondary school, the average number of dependants was 4 (four) people, and the average cultivated land was 0.59 ha/ farmer.

The data was analysed by using MDS method. The MDS analysis was performed by using Rapid appraisal for community forestry (RapCF) which was developed from Rapfish (Pitcher \& Preikshot, 2001). There were five dimensions (ecology, economic, social, institutional, technology dimension) and 29 attributes used in this research. The attribute valuation was in ordinal scale based on the sustainability criteria of each dimension (Supplement 1). The criteria were ranked from 0 (the lowest) to 3 (the highest). The assessment of sustainability index was categorised into four groups (Kavanagh \& Pitcher, 2004), namely: not sustainable $(0-25 \%)$, less sustainable $(>25-50 \%)$, moderate sustainable $(>50-75 \%)$ and good sustainable $(>75-100 \%)$. The level of sustainability dimensions was displayed simultaneously by using kite diagrams.

\section{c. Analysis}

The evaluation of sustainability index was followed up by the determination of the leverage factors and Monte Carlo analysis. The leverage analysis was used to find the sensitive sustainability attributes based on RMS value (Kavanagh \& Pitcher, 2004). The higher the RMS value, the greater the attribute effect on the level of sustainability. The RMS value was obtained through the equation as follows: 


$$
R M S=\sqrt{\sum_{i=1}^{n} a_{i}^{2}}
$$

$a=$ standard error,

Monte Carlo analysis was used to determine the random error of all dimensions. The results of Monte Carlo analysis was compared to those of MDS analysis, as a result is $95 \%$ degree of confidence, hence it could be determined that the difference value between the results was approximately $5 \%$. Furthermore, if the difference was $<5 \%$, the MDS result was sufficient to predict the sustainability of community forestry.

The final stage was the goodness of fit using S-stress value by calculating the values of $S$ and $R^{2}$. The lower the $S$, the higher the goodness of fit. The $S$ value was set based on Kavanagh \& Pitcher (2004), namely $S<0.25$.

\section{Results and Discussion}

a. The level sustainability of $\mathrm{HKm}$ in Babak watershed

The result showed that the sustainability of $\mathrm{HKm}$ in Babak watershed was in moderate sustainability with the average sustainability index of dimensions of $54.08 \%$. It means that in general, the performance of $\mathrm{HKm}$ in Babak watershed was fairly good, hence the goals of community forestry can be achieved despite of its sub-optimally yield. Among all dimensions, the ecology and technology were classified in the level of less sustainable. Based on the results, the ecology and technology should become the priorities for further improvement to enhance the level of $\mathrm{HKm}$ sustainability. Subsequently, the institutional dimension obtained the highest sustainability index, while the ecology had the lowest sustainability index (Figure 2).

The leverage analysis on $\mathrm{HKm}$ indicated only 11 out of 29 attributes were categorised as sensitive attributes, specifically 3 (three) attributes of ecological, 4 (four) attributes of economic, 2 (two) attributes of social, and also one attribute for each of institutional and technology dimension. Those attributes can be prioritised to augment the sustainability level of $\mathrm{HKm}$ in Babak watershed. The higher the RMS value means the greater the attribute role in sustainability level (Kavanagh \& Pitcher, 2004). The result showed that the highestRMS value was gained by the farmer groups join activity (RMS 13.95), while the lowest was the participation in community forestry (RMS $0.15)$, which were included in the institutional and social dimension, respectively (Table 1). It means that the farmer groups'activity contributed highly on the sustainability index compared to the participation in community forestry.

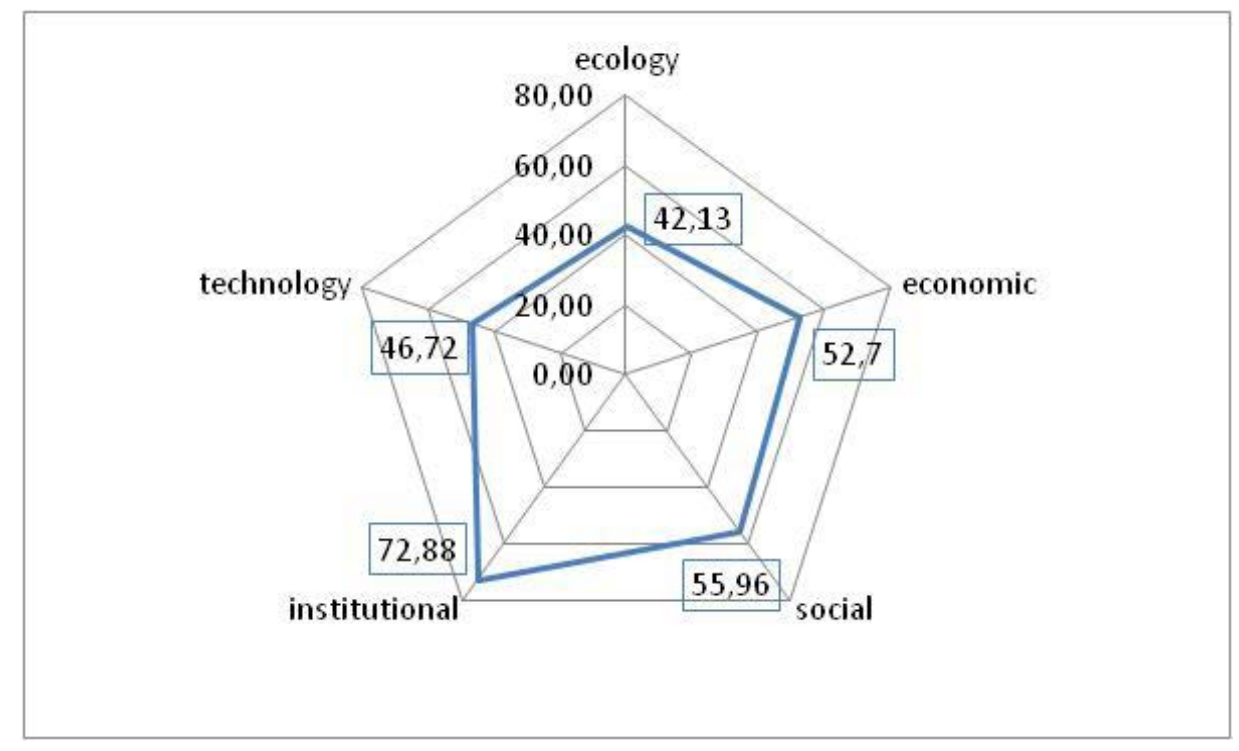

Figure 2. Sustainability level of HKm in Babak watershed 
Table 1. The RMS value of attributes and dimensions based on leverage analysis of HKm in Babak watershed.

\begin{tabular}{|c|c|c|}
\hline Dimension & Attribute & RMS \\
\hline \multirow[t]{7}{*}{ Ecology } & Runoff & $3.89 *$ \\
\hline & Soil erosion & $6.06^{*}$ \\
\hline & Land productivity & 1.02 \\
\hline & The use of soil conservation & 1.58 \\
\hline & Land cover & $6.13^{*}$ \\
\hline & Vegetation diversity & 1.79 \\
\hline & Land cultivation area & 3.36 \\
\hline \multirow[t]{7}{*}{ Economic } & Sum of product & 2.12 \\
\hline & Product market & $4.03^{*}$ \\
\hline & Contribution of community forestry farming income & $4.15^{*}$ \\
\hline & Contribution of non-community forestry farming income & $4.27^{*}$ \\
\hline & Poverty level & $5.50^{*}$ \\
\hline & Family member dependants & 0.80 \\
\hline & Adaptation of agricultural commodities demand & 1.58 \\
\hline \multirow[t]{4}{*}{ Social } & Education level & $9.99 *$ \\
\hline & Perception of soil conservation activity & 1.33 \\
\hline & Perception of community forestry activity & $9.51^{*}$ \\
\hline & Participation in community forestry & 0.15 \\
\hline \multirow[t]{5}{*}{ Institutional } & Farmer groups activity & $13.95^{*}$ \\
\hline & Farmer accompaniment & 6.61 \\
\hline & Knowledge of institutional rules/awig-awig & 6.60 \\
\hline & Decision-making process on farmer groups & 6.61 \\
\hline & Leadership on farmer groups & 6.71 \\
\hline \multirow[t]{6}{*}{ Technology } & Land preparation & 1.86 \\
\hline & Planting & 2.43 \\
\hline & Plant maintenance & 2.47 \\
\hline & Harvesting & $6.85^{*}$ \\
\hline & Post-harvesting processing & 2.75 \\
\hline & Type of soil conservation & 2.60 \\
\hline
\end{tabular}

Description: * is sensitive attribute.

The soil erosion, runoff, and land cover as the ecology attributes and the harvesting included as the technology attribute were considered sensitive to the sustainability level. The soil erosion, runoff, and land cover are three attributes that are highly inter-correlated (Cadaret et al., 2016; Zokaib \& Naser, 2012; Ochoa et al., 2016).The improvement of land management can be implemented to reduce the runoff and soil erosion, such as land restoration and also soil and water conservation application (Miardini \& Susanti 2016).The land restoration can be done by intensification and diversification of the land use. This matter is also a part of the improvement of an economic attribute related to the farmer incomes as suggested by Winata et al. (2015), although the sustainability of economic dimension was in moderate level. However, in $\mathrm{HKm}$, the intensification could not be done easily due to the prevailing regulation of forest utilisation as stated in the Government Regulation No. $6 / 2007$, even it is possible for the diversification of land use. In addition to land restoration, the law enforcement of composition in forest area, which is $70 \%$ of timber and $30 \%$ of Multipurpose trees species (MPTS) should be maintained.

The income of farmers is one attribute of economic dimension which is sensitive to sustainability level of $\mathrm{HKm}$ in Babak watershed 
in pertaining to the land area (Winata et al., 2015). The income of farmers determines the poverty level (Badan Pusat Statistik Provinsi $N T B, 2014)$, thus that the enhancement of this attribute can support other dimensions. The determination of land area for $\mathrm{HKm}$ should be focused on the minimum area to prop up proper life. The average minimum area for proper life in HKmof Babak watershed is 1.62 hectares. However, it is unattainable because of the forest management license issued by the government as $\mathrm{HKm}$ (IUPHHKm) is limited, while the farmer has active involvement in $\mathrm{HKm}$. It can be addressed by changing the land management by increasing the productivity of the land (Febryano, 2008; Mu'min et al., 2014), but still retaining the composition of $30 \%$ timber and $70 \%$ MPTS based on the rule of forest utilisation at the same time. The land management can be done through the land intensification and diversification (Wijayanti et al., 2016) as an attempt to increase the farmer's income.

The harvesting technique is the sensitive attribute of technology dimension in $\mathrm{HKm}$. Generally, the farmers rely on the wholesaler to harvest their products. Although it is disadvantageous for the farmers, the role of the wholesaler is crucial due to the difficulties in facilities provision and the lack of information of the markets network. Syahza (2003) asserted those difficulties as the common constraints that hinder the success of the agribusiness sector. In order to overcome this constraint, the establishment of a rural economic institution which among of the functions is to regulate the products marketing is required (Syahza, 2003). In $\mathrm{HKm}$, the rural economic institution can be in the form of cooperative as a part of management unit in the farmers group. The establishment of cooperative under the farmers group requires assistance until the institution is stable and autonomous.

Based on the MDS analysis, the HKm of Babak watershed has a high validity and goodness of fit, hence it can be used as the basic evaluation of the sustainability of $\mathrm{HKm}$ in Babak watershed. It was indicated by Monte Carlo and goodness of fit analysis in which the difference between MDS result and Monte Carlo analysis of each dimension was very low (Table 2).

Table 2. The result of Monte Carlo analysis at $95 \%$ degree of confidence in HKm of Babak watershed.

\begin{tabular}{lccc}
\hline \multicolumn{1}{c}{ Dimension } & MDS & Monte Carlo & Difference (\%) \\
\hline Ecology & 42.13 & 42.29 & -0.19 \\
Economic & 52.7 & 52.08 & 0.59 \\
Social & 55.96 & 55.91 & 0.04 \\
Institutional & 72.88 & 72 & 0.61 \\
Technology & 46.72 & 46.64 & 0.1 \\
\hline
\end{tabular}

Based on Kavanagh and Pitcher (2004), it explicated that the attributes scoring of each sustainability dimension was classified appropriate so that those attributes were reliable to evaluate the sustainability level of $\mathrm{HKm}$ in Babak watershed. The result of the goodness of fit analysis showed that $R^{2}$ had a very high value in all dimension, while $S$ value had very low value (Table 3 ). Based on Kavanagh and Pitcher (2004), it means that the MDS analysis in HKm of Babak watershed is appropriate so that it was reliable to evaluate the sustainability level of $\mathrm{HKm}$ in Babak watershed.

Table 3. The results of the goodness of fit analysis of HKm in Babak watershed.

\begin{tabular}{cccccc}
\hline & Ecology & Economy & Social & Institution & Technology \\
\hline $\mathrm{S}$ & 0.14 & 0.14 & 0.15 & 0.14 & 0.15 \\
$\mathrm{R}^{2}$ & 0.94 & 0.94 & 0.95 & 0.95 & 0.94 \\
\hline
\end{tabular}


b. The sustainability level of private forest in Babak watershed

The result demonstrated that the sustainability of private forest in Babak watershed was classified in less sustainable level with an average sustainability index of $48.53 \%$. It means that in general, private forest in Babak watershed was less optimal; hence the improvement of several attributes was needed to achieve the goal of community forestry. Among the dimensions, the institution and technology were included in the less sustainable level. According to the results, the improvement of institutional dimension and technology should be the main concerns. Thus the sustainability level of private forest would be increased. The social aspect obtained the highest sustainability index, while the technological dimension had the lowest sustainability index (Figure 3).

The leverage analysis of private forest showed that only 19 from 29 attributes were categorized as sensitive attributes, particularly 5 (five) attributes of ecology, 5 (five) attributes of economy, 2 (two) attributes of social, and also 5 (five) attributes of institution, and also 2 (two) attributes of technology. Those attributes can be prioritised in order to increase the sustainability level of private forest in Babak watershed. The result indicated that the highest value of RMS was the perception of soil conservation activity (RMS 10.95), while the lowest was the participation in community forestry (RMS 0.03), and both of them were attributes of social dimension (Table 4). It means that the perception of soil conservation activity highly contributed to the sustainability index by comparing with the leadership of farmer groups.

Furthermore, all attributes of institutional dimension were sensitive, while the plant maintenance and type of soil conservation as the attributes of technology were sensitive for the sustainability level of the private forest. The institution of the private forest was dormant due to several reasons including few activities of farmer groups, the absence of farmer assistance, ineffective rules of farmer groups, less involvement of the farmers in decision-making and less passage of the leadership in farmer groups. The development of private forest institution was initiated by the government through the forestry extension under the scheme of land rehabilitation. Forestry extension serves as the initiator that mentors, facilitates, and promotes the farmer groups of private forest as stated by Uphoff (1986). The initiator has power to influence the participation of the institution members (Pretty, 1995).

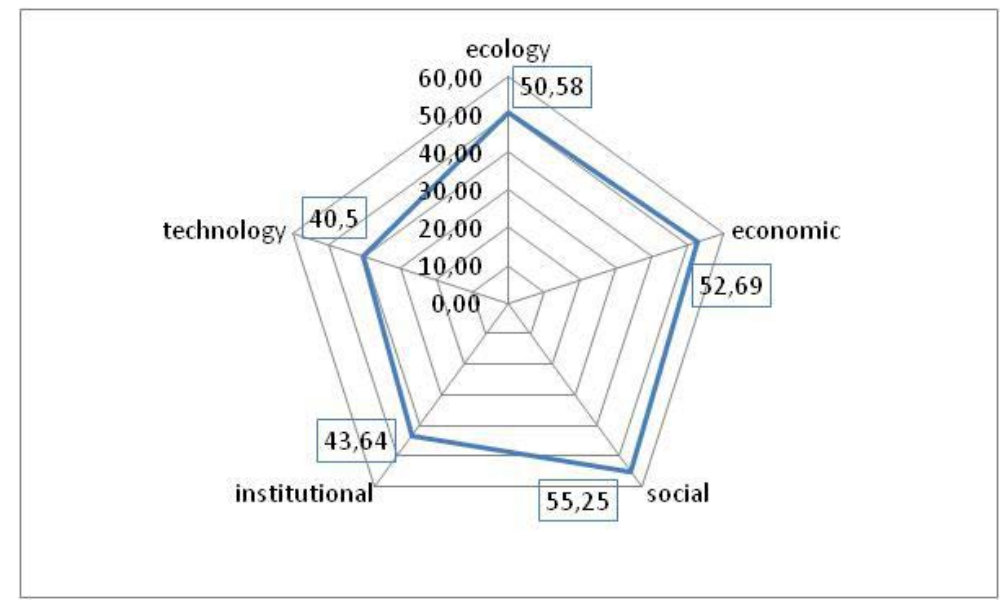

Figure 3. Sustainability level of private forest in Babak watershed

Based on the interviews, theinstitution was determined as inactive since the initiator did not provide mentoring, facility, and promotion for the farmer groups. It means that the initiator has been successfully building the frame, structure and mechanism (rules) of the institution,yet failed to raise the autonomous of institution (Djogo et al., 2003). The condition should be 
overcome by participatory capacity building and community empowerment (Uphoff et al., 2006; Awang et al., 2008). The institution built based on the local participatory depends on the leadership (Sheelanere et al., 2013), so that the leadership must be constructed suspiciously according to the mutual trust within the farmer group to motivate and support the institutional activity. If the leadership functions properly, the attributes of institutional dimension such as the activity of farmer groups, farmer accompaniment, the rules/awig-awig practices, and also decisionmaking would function properly.

Table 4. The RMS value of each attribute and dimension based on leverage analysis of private forest in Babak watershed

\begin{tabular}{|c|c|c|}
\hline Dimension & Attribute & RMS \\
\hline \multirow[t]{7}{*}{ Ecology } & Runoff & $5.40^{*}$ \\
\hline & Soil erosion & $6.91^{*}$ \\
\hline & Land productivity & $7.54^{*}$ \\
\hline & The use of soil conservation & $9.12 *$ \\
\hline & Land cover & 4.18 \\
\hline & Vegetation diversity & 3.93 \\
\hline & Land cultivation area & $5.11^{*}$ \\
\hline \multirow[t]{7}{*}{ Economy } & Sum of product & $4.41^{*}$ \\
\hline & Product market & $6.39^{*}$ \\
\hline & Contribution of community forestry farming income & $5.52 *$ \\
\hline & Contribution of non-community forestry farming income & $6.38^{*}$ \\
\hline & Poverty level & $5.71^{*}$ \\
\hline & Family member dependants & 1.77 \\
\hline & Adaptation of agricultural commodities demand & 2.97 \\
\hline \multirow[t]{4}{*}{ Social } & Education level & 2.00 \\
\hline & Perception of soil conservation activity & $10.95^{*}$ \\
\hline & Perception of community forestry activity & $9.55^{*}$ \\
\hline & Participation in community forestry & 0.03 \\
\hline \multirow[t]{5}{*}{ Institution } & Farmer groups activity & $2.34^{*}$ \\
\hline & Farmer accompaniment & $1.82 *$ \\
\hline & Knowledge of institutional rules/awig-awig & $1.62 *$ \\
\hline & Decision-making process on farmer groups & $2.70^{*}$ \\
\hline & Leadership on farmer groups & $1.76^{*}$ \\
\hline \multirow[t]{6}{*}{ Technology } & Land preparation & 0.60 \\
\hline & Planting & 0.28 \\
\hline & Plant maintenance & $4.45^{*}$ \\
\hline & Harvesting & 0.04 \\
\hline & Post-harvesting processing & 0.50 \\
\hline & Type of soil conservation & $3.48^{*}$ \\
\hline
\end{tabular}

Description: * is sensitive attribute.

The plant maintenance and type of soil conservation were the sensitive attributes of technology dimension of private forest in Babak watershed. Based on the interview, private forest farmers did not applied the intensive silviculture such as prime seeds selection, fertilisation, pest control, and also crop thinning as the plant maintenance (Soekotjo, 2009). The plants grow naturally without any treatment; hence the growth was less optimal. The soil and water conservation was not applied in the private forest because 
the majority was located in a flat area and safe from the erosion. Nevertheless, the soil conservation can be applied as mitigation in the form of the preference of specific type of vegetation that can improve land quality, e.g., a legume.

The MDS analysis of private forest in Babak watershed had a high validity and goodness of fit, so that it can be used as the basic evaluation for the sustainability of $\mathrm{HKm}$ in Babak watershed. The results generated from Monte Carlo and goodness of fit analysis, in which the difference of the results of MDS analysis and those of Monte Carlo analysis of each dimension was very low (Table 5).

Table 5. The result of Monte Carlo analysis in 95\% of confidence of private forest in Babak watershed.

\begin{tabular}{lccc}
\hline \multicolumn{1}{c}{ Dimension } & MDS & Monte Carlo & Difference (\%) \\
\hline Ecology & 50.58 & 50.08 & 0.50 \\
Economy & 52.69 & 52.08 & 0.61 \\
Social & 55.25 & 54.13 & 1.01 \\
Institution & 43.64 & 43.55 & 0.01 \\
Technology & 40.5 & 40.16 & 0.42 \\
\hline
\end{tabular}

Based on Kavanagh and Pitcher (2004), the attributes scoring of each dimension of sustainability was classified appropriate, so that those attributes were accurate to evaluate the sustainability level of private forest in Babak watershed. The result of the goodness of fit analysis showed that $R^{2}$ had a very high value among all dimensions, while $S$ value had very low value (Table 6). Based on Kavanagh and Pitcher (2004), it means that the MDS analysis of private forest in Babak watershed was appropriate, it was accurate to evaluate the sustainability level of private forest in Babak watershed.

Table 6. The result of the goodness of fit analysis of private forest in Babak watershed.

\begin{tabular}{cccccc}
\hline & Ecology & Economy & Social & Institution & Technology \\
\hline $\mathrm{S}$ & 0.14 & 0.14 & 0.15 & 0.16 & 0.16 \\
$\mathrm{R}^{2}$ & 0.94 & 0.94 & 0.95 & 0.94 & 0.94 \\
\hline
\end{tabular}

\section{Conclusions and Recommendations}

The evaluation of the sustainability level of community forestry in Babak watershed carried out by using MDS indicated that the $\mathrm{HKm}$ in this area was classified in moderate sustainability level (sustainability index $54.08 \%$ ) and the private forest was categorised in less sustainability level (sustainability index $48.53 \%$ ). Moderate sustainability in $\mathrm{HKm}$ means that the HKm was fairly good, so that the goal of community forestry can be achieved even if it has not been optimal yet. Less sustainability in private forest means that the improvement of several attributes is required to achieve the goal of community forestry. In $\mathrm{HKm}$, the ecological dimension and technological dimension were categorised in less sustainability level, the while institutional and technological dimension of private forest were classified in less sustainability level. There were 11 sensitive attributes of $\mathrm{HKm}$ and 19 sensitive attributes of private forest; hence, improvement of the sensitive attributes was highly required in order to increase the sustainability level of community forestry in Babak watershed. The priority of attribute improvement in $\mathrm{HKm}$ includes land restoration (the ecological dimension) and also the cooperative establishment (the technological dimension). In private forest, the priority of attribute improvement includes the leadership capacity building (the institutional dimension) and also the use of intensive silviculture and soil conservation (the technological dimension).

The land restoration can be done by the diversification of the land use. The diversification both in $\mathrm{HKm}$ and private can be done by adding the different types of plant, 
which has dense canopy and multiple benefits such as MPTS. However, the plant composition of $\mathrm{HKm}$ must follow the requirement of $70 \%$ timber and $30 \%$ as determined by the rule of forest utilisation in The Indonesian Governmental Decree (PPRI) No. 6/2007. The establishment of a cooperative under the farmer groups is required to regulate the marketing of the product. It is a solution to overcome the product marketing constraints, hence the farmers will not relied solely on the wholesaler. Leadership is a key for the autonomous institution, so the capacity building must be done to have a good leadership in a farmer groups of $\mathrm{HKm}$ and private forest. The intensive silviculture should be done as the plant maintenance to improve the quality of the community forestry products. It includes the prime seeds selection, fertilization, pest control, and crop thinning. Although private forest is unsusceptible from the erosion, the soil and water technique of conservation is required as the prevention. It can be done by planting specific types of vegetation that can improve the land quality, e.g., legume.

\section{Acknowledgements}

The authors would like to acknowledge the members of $\mathrm{HKm}$ farmer groups in Setiling, Aik Berik, Karang Sidemen and Lantan as well as the members of private forest farmer groups in Pemepek, Setiling and Sepakek, as the participants in this research. This paper was carried out as the part of $\mathrm{PhD}$ thesis funded by the Ministry of Forestry and Environment of the Republic of Indonesia, hence we also express our gratitude for the institution for the financial support.

\section{References}

Aji, G.B., Yuliyanti, Suryoko, J., Ekaputra, A.D., Saptono, T. Muis, H. (2015) Sumbangan Hutan Kemasyarakatan dan Hutan Desa terhadap Pendapatan dan Pengurangan Kemiskinan. Jakarta: The Partnership for Governance Reform, Kerjasama LIPI dan Kemitraan.

Asdak, C. (2010) Hidrologi dan Pengelolaan DAS. Edisi Kelima. Yogyakarta: Gadjah Mada University Press.

Awang, S.A., Widayanti, W.T., Himmah, B. Astuti, A., Septiana, R.M., Solehudin, Novenanto, A. (2008) Panduan Pemberdayaan Lembaga Masyarakat Desa Hutan (LMDH). L. Santoso, S. A. Awang, and W. T. Widayanti (eds). Jakarta: CIRAD, CIFOR dan PKHR.

Badan Pusat Statistik Propinsi NTB. (2014) Nusa Tenggara Barat dalam Angka. Badan Pusat Statistik Propinsi NTB.

BP DAS DodokanMoyo Sari. (2008) Rencana Kerja Evaluasi dan Monitoring Pembangunan Hutan Kemasyarakatan di Propinsi Nusa Tenggara Barat. Mataram.

Budiharsono, S. (2014) Manual Penentuan Status dan Faktor Pengungkit untuk Perencanaan dan MonevPengembangan Ekonomi Lokal. Jakarta: Bappenas.

Cadaret, E.M., McGwire, K.C., Nouwakpo, S.K., Weltz, M.A., Saito, L. (2016) Vegetation Canopy Cover Effects on Sediment Erosion Processes in the Upper Colorado River Basin Mancos Shale Formation, Price, Utah, USA. Catena. 147. pp.334-344. Available at: http://dx.doi. org/10.1016/j.catena.2016.06.043.

Djogo, T., Sunaryo, Suharjito, D., Sirait, M. (2003) Kelembagaan dan Kebijakan dalam Pengembangan Agroforestri. Bogor: ICRAF.

Febryano, I. (2008) Analisis Finansial Agroforestri Kakao di Lahan Hutan Negara danLahan Milik. Jurnal Perennial. 4(1). pp.41-47.

Fiquepron, J., Garcia, S. and Stenger, A., (2013) Land Use Impact on Water Quality: Valuing Forest Services in Terms of the Water Supply Sector. Journal of Environmental Management. 126. pp.113-121. Available at: http://dx.doi.org/10.1016/j.jenvman.2013.04.002.Hazarika, S., Thakuria, D., Ganeshamurthy, A.N., Sakthivel, T. 2014. Soil Quality as Influenced by Land Use History of Orchards in Humid Subtropics. Catena. 123. pp.37-44. Available at: http:// 
dx.doi.org/10.1016/j.catena.2014.07.006.

Hazarika, A., Mandal, M., Maji, T.K. (2014) Dynamic mechanical analysis, biodegradability and thermal stability of wood polymer nanocomposites. Composites Part B: Engineering 60, 568-576.

Irawan, E. (2011) Nilai Ekonomi Hutan Rakyat untuk Penyerapan Emisi Karbon. Jurnal Penelitian Sosial dan Ekonomi Kehutanan. 8(1). pp.54-70.

Irawanti, S., Suka, A.P. and Ekawati, S. (2012) Manfaat Ekonomi dan Peluang Pengembangan Hutan Rakyat Sengon di Kabupaten Pati. Jurnal Penelitian Sosial Ekonomi Kehutanan. 9(3). pp.126-139.

Kavanagh, P. and Pitcher, T. (2004) Implementing Microsoft Excel Software For Rapfish: A Technique for The Rapid Appraisal of Fisheries Status. Fisheries Centre Research Report. 12(2). Canada: University of British Columbia.

Kementrian Kehutanan (2014) Statistik Kementerian Kehutanan Tahun 2013. Jakarta: Kementerian Kehutanan.

Khanal, B. (2011) Is Community Forestry Decreasing The Inequality among Its Users? Study on Impact of Community Forestry on Income Distribution among Different Users Groups in Nepal. International Journal of Social Forestry.4(2).pp.139-152.

Li, R., Bennett, J. and Wang, X. (2013) Predicting Environmental Impacts for Assessing Land Use Change Options in Sichuan Province, China. Land Use Policy. 30(1). pp.784-790. Available at: http://dx.doi.org/10.1016/j.landusepol.2012.05.019.

Miardini, A. and Susanti, P.D. (2016) Analysis Physical Characteristics of Land for Estimated Runoff Coefficient as Flood Control Effort in Comal Watershed, Central Java. Forum Geografi. 30(July).pp.58-68.

Mu'min, A., Hastuti, K.P. andAngriani, P. (2014) Pengaruh Diversifikasi Pertanian terhadap PendapatanMasyarakat di Desa Belawang Kecamatan Belawang Kabupaten Barito Kuala. Jurnal Pendidikan Geografi. 1(3). pp.8-20. Available at: http://ppjp.unlam.ac.id/journal/ index.php/jpg.

Murtilaksono, K. (2014) Penetapan Klasifikasi DAS Wilayah Kerja BPDAS Dodokan Moyo Sari. In Sosialisasi Klasifikasi DAS dan FGD Perlindungan Mata Air di NTB. Mataram: BPDAS Dodokan Moyo Sari.

Nandini, R. (2013) Evaluasi Pengelolaan Hutan Kemasyarakatan (HKm) pada Hutan Produksi dan Hutan Lindung di Pulau Lombok. Jurnal Penelitian Hutan Tanaman. 10(1). pp.43-55.

Nazam, M. Sabiham, S., Pramudya, B., Widiatmaka, Rusastra, I.W. (2011) Penetapan Luas Lahan Optimum Usahatani Padi Sawah Mendukung Kemandirian Pangan Berkelanjutan di Nusa Tenggara Barat. Jurnal Agro Ekonomi. 29(2). pp.113-145.

Nkem, J. (2006) A Forest Platform for Climate Change Adaptation for Africa. Accra: UFCCC African Regional Climate Change Vulnerability and Adaptation.

Nunes, A.N., De Almeida, A.C. and Coelho, C.O.A. (2011) Impacts of Land Use and Cover Type on Runoff and Soil Erosion in a Marginal Area of Portugal. Applied Geography. 31(2). pp.687-699. Available at: http://dx.doi.org/10.1016/j.apgeog.2010.12.006.

Nurwanti, E. (2014) Evaluasi Dampak Lingkungan Hutan Rakyat Terhadap Erosi Tanah serta Sosial Ekonomi, Budaya Masyarakat Studi Kasus di Desa Rumah Gerat Kecamatan Sibirubiru. Available at: www.researchgate.net[Accessed October 14, 2014].

Ochoa, P.A., Fries, A., Mejía, D., Burneo, J.I., Ruíz-sinoga, J.D., Cerdà, A. (2016) Effects of Climate, Land Cover and Topography on Soil Erosion Risk in a Semiarid Basin of the Andes. Catena. 140. pp.31-42. Available at: http://dx.doi.org/10.1016/j.catena.2016.01.011.

Pikun, H. (1998) Social Forestry Theories and Practices. In Social Forestry Theories and Practices. Kunming City: Yunan Nationality Press. 
Pitcher, T.J. and Preikshot, D. (2001) RAPFISH : A Rapid Appraisal Technique to Evaluate The Sustainability Status of Fisheries. Fisheries Research. 49. pp.255-270.

Pokharel, R.K., Raj, P., Raj, K., Köhl, M. (2015) Assessing the Sustainability in Community Based Forestry: a Case from Nepal. Forest Policy and Economics. 58. pp.75-84. Available at: http:// dx.doi.org/10.1016/j.forpol.2014.11.006.

Pretty, J.N. (1995) Participatory Learning for Sustainable Agriculture. World Development. 23(8). pp.1247-1263.

Rahayu, S., Setiawan, E. and Suyanto (2010) Sistem Agroforestri di Kawasan Penyangga Hutan Lindung Sesaot: Potensinya sebagai Penambat Karbon. Brief No.7 Policy Analysis Unit. World Agroforestry Centre.

Ritonga, W.M. and Rochana, E. (2013) Keberhasilan Program Hutan Kemasyarakatan dalam Melestarikan Hutan. Jurnal Sociologie. 1(2).pp.132-137.

Sevillla, C.G., Ochave, J.A., Punzalan, T.G., Regalla, B.P., Uriarte, G.G. (2007) Research Methods. Quezon City: Rex Printing Company.

Sheelanere, P., Noble, B.F. and Patrick, R.J. (2013) Institutional Requirements for Watershed Cumulative Effects Assessment and Management : Lessons from a Canadian Trans-boundary Watershed. Land Use Policy. 30(1). pp.67-75. Available at: http://dx.doi.org/10.1016/j. landusepol.2012.03.001.

Soekotjo (2009) Silvikultur Intensif (SILIN). Yogyakarta: Gadjah Mada University Press.

Sukwika, T., Darusman, D., Kusmana, C., Nurrochmat, D.R. (2016) Evaluating The Level of Sustainability of Privately Managed Forest in Bogor, Indonesia. Biodiversitas.17(1).pp.241-248.

Suwarno, J., Kartodihardjo, H., Pramudya, B., Rachman, S. (2011) Pengembangan Kebijakan Pengelolaan Berkelanjutan DAS Ciliwung Hulu Kabupaten Bogor. Jurnal Analisis Kebijakan Kehutanan. 8(2). pp.115-131.

Syahza, A. (2003) Paradigma Baru: Pemasaran Produk Pertanian Berbasis Agribisnis di Daerah Riau. Jurnal Ekonomi, VIII(01), pp.1-11.

Uphoff, N., Buck, L. and Sjorslev, J. (2006) Strenghtening Rural Local Institutional Capacities for Sustainable Livehoods and Equitable Development. J. Sjorslev (ed.) 21 August. Washington. DC: The Social Development Department of The World Bank.

Uphoff, N.T. (1986) Local Institutional Development: an Analytical Sourcebook with Cases. United States of America: Kumarian Press.

Widiatmaka, Munibah, K. and Sitorus, S.R.P. (2015) Appraisal Keberlanjutan Multidimensi Penggunaan Lahan untuk Sawah di Karawang-Jawa Barat. Kawistara. 5(2). pp.113-131.

Wijayanti, R., Baiquni, M., and Harini, R. (2016) Strategi Penghidupan Berkelanjutan Masyarakat Berbasis Aset di Sub DAS Pusur, DAS Bengawan Solo. Jurnal Wilayah dan Lingkungan. 4(2). pp.133-152.

Winata, N.G.A.W., Basuki, P. and Karismawan, P., (2015) Analisis Determinan Pendapatan Petani Program Hutan Kemasyarakatan (HKm) di Kecamatan Batukliang Utara Kabupaten Lombok Tengah. Jurnal Sosial Ekonomi E Humaniora. 1(1). pp.33-42. Available at: http://jurnal.unram. ac.id/index.php/jseh.

Yan, B., Fang, N.F., Zhang, P.C., Shi, Z.H. (2013) Impacts of Land Use Change on Watershed Streamflow and Sediment Yield: An Assessment Using Hydrologic Modelling and Partial Least Squares Regression. Journal of Hydrology. 484. pp.26-37. Available at: http://dx.doi. org/10.1016/j.jhydrol.2013.01.008.

Zokaib, S.and Naser, G. (2012) Impacts of Land Uses on Runoff and Soil Erosion A Case Study in Hilkot Watershed Pakistan. International Journal of Sediment Research.26(3).pp.343-352. Available at: http://dx.doi.org/10.1016/S1001-6279(11)60098-X. 
Supplement 1 . The attribute and criteria appraisal of community forestry sustainability in Babak watershed.

Attribute

Description

Criteria

Ecology

1. Runoff

2. Erosion

3. Land productivity (quintal/ha)

4. The use of soil conservation

5. Land cover (\%)

6. Vegetation diversity

7. Land cultivation area (hectare)

Economic:

1. Sum of product

2. Product market

3. Contribution of community forestry farming income

4. Contribution of non community forestry farming income

5. Poverty level

6. Family member dependants

7. Adaptation on agricultural commodities demands

Social:

1. Education level

2. Perception on soil conservation activity

3. Perception on community forestry activity

4. Participation in community forestry activity

Institutional:

1. Farmers groups activity

2. Farmers accompaniment

3. Knowledge of institutional rules/ awig-awig

4. Decision-making process on The actors of decision making in farmfarmers groups

5. Leadership on farmers groups
Physical data

Physical data

Land productivity appraisal by rice equivalence that occur in those area

Knowledge of soil conservation

Vegetation density in community forestry

Variety of vegetation

The area of land cultivation compare with the minimum area to proper life (MAPL)

Sum of product from the land

The pattern of product market

Percentage of income from community forestry

Percentage of income beside of community forestry

Poverty rate (PR)

The member of family

The changing to fulfil the agricultural commodities demand

The level education of family member

The perception on soil conservation benefit

The perception on community forestry activity

The frequency of participation in community forestry activity

The farmers activity in groups a year

The frequency of farmers accompaniment a year

Knowledge of institutional rules/ awig-awig ers groups ers groups

High (0), moderate (1), low (2), very low (3)

High (0), moderate (1), low (2), very low (3)

none (0), less (1), equal (2), greater (3)

Not know, not use (0), know, not use (1), not know, use (2), know, use (3)

$<25 \%$ (0), >25-50\% (1), >50-75\% (2)

$>75-100 \%$ (3)

$<3$ (0), 3-6 (1), >6-10 (2), >10 (3)

No land (0), less from MAPL (1), equal to MAPL (2), greater than MAPL (3)

$<3$ (0), 3-6 (1), >6-10 (2), >10 (3)

Not for sale (0), wholesaler (1), collectors (2), public market (3)

$<25 \%(0),>25-50 \%$ (1), $>50-75 \%$ (2), $>75-100 \%$ (3)

$>75-100 \%$ (0), >50-75\% (1), >25-50\% (2) $<25 \%$ (3),

Under PR (1), equal to PR (2), above PR (3)

$>7(0),>5-7(1),>3-5(2), 1-3(3)$

none (1) yes, no effort (2), yes, with ef fort (3),

none (0), primary school to junior high school (1), senior high school (2), college (3)

No benefit (0) less benefit (1), moderate benefit (2), great benefit (3),

poor (1), moderate (2), good (3)

never (1), sometimes (2), always(3)

none (0), 1-2 activity (1), 3-4 activity (2), $\geq 5$ activity

none 0$), 1-2 \times(1), 3-4 \times(2), \geq 5 \times(3)$

Not know (0), none (1), yes, no sanctions (2) yes, with sanctions (3)

Not know (0), government/ facilitator (1), caretaker (2), member (3)

The appraisal of leadership on farm- Not know (0), poor (1), moderate (2), $\operatorname{good}(3)$ 


\begin{tabular}{lll}
\hline \multicolumn{1}{c}{ Attribute } & Description & Criteria \\
\hline Technology: & & \\
\hline
\end{tabular}

1. Land preparation

Type of land preparation

2. Planting

3. Plant maintenance

4. Harvesting

5. Post-harvest processing

6. Type of soil conservation
Planting implementation

Type of plant maintenance

Type of harvesting

Type of post-harvest processing

Type of soil conservation burnt(0), clear cutting (1), fertilized (2), clear cutting and fertilized (3)

Direct kernel planting (0), direct seed planting (1), planting with type arrangement (2), planting with distance arrangement (3)

None (0), 1 maintenance (1) 2-4 maintenance (2), $\geq 5$ maintenance (3)

none (0), harvesting by wholesaler (1), self harvesting without arrangement (2) gradually arrangement (3)

None (0), raw product (1), processed in the same product (2), processes in other product (3)

none (0), vegetative conservation (1), civil technique conservation (2), vegetative and civil technique conservation (3) 